\title{
The Effects of the 2001 Economic Crisis of Turkey on Holding Companies' Diversification Strategies: Does Bank Ownership Make Difference?
}

\author{
Yucel Turker ${ }^{1}$, Alp Polat ${ }^{2}$ \& Huseyin Kose ${ }^{3}$ \\ ${ }^{1}$ Osmangazi University, Turkey \\ ${ }^{2}$ Bilecik Seyh Edebali University,Turkey \\ ${ }^{3}$ Anadolu University, Turkey \\ Email: yturker@ogu.edu.tr \\ DOI: https://doi.org/10.37134/jcit.vol7.5.2017
}

\begin{abstract}
The objective of the study is to search whether there are any changes in holding companies' diversification strategies before 2001 and after 2001 in Turkey. In this context, which diversification strategies (related or unrelated) are adopted by the holding companies is tried to be determined. The holding companies included in study divided into two groups one of them is before the economic crisis of 2001 having bank and continue in the same way after 2001 and the rest. On this basis, whether having bank is advantageous in diversification strategies or not is tested. Quantitative research is used for reaching on planned data. The data related with holding companies are obtained by Istanbul Stock Exchange. Holding companies and sectors they performed and the sectors' relationships are tried to be put forward. The study concludes that 2002 economic crisis enhance the diversification especially for bank owner holding companies due to the fact that the crisis provides opportunities which can be easily used by the holding companies that have strong banks.
\end{abstract}

Keywords Istanbul stock exchange, Diversification, Economic crisis, Holding companies

\section{Introduction}

The papers which investigate holding companies have been increasing in Turkey. Usdiken (2008) states that interest of researchers regarding holding companies has been started since mid-1990s. Academic studies stress out that holding company forms is peculiar to late industrialized markets (Khanna and Palepu, 2000; Yiu et al., 2005; Chung et al., 2006; Kedia et. al.., 2006;). Bugra (1995) defines these markets and states that late industrialized markets are the economies which industrialized without using national production capacity.

The researches about holding companies focus on diversification strategies and presents contrarian hypotheses. Guillen (2000) analyses South Korea, Latin America, India and Turkey and concludes that these countries have unrelated diversification. Karaevli (2008) suggests the idea that Turkey has been experiencing focused diversification rather than unrelated diversification.

This study investigates the impact of the 2001 Economic Crisis of Turkey on Holding Compaines' diversification strategies. Chang (2006) claims that the 1997 Asia crisis negatively affect holding companies and highlights the fact that holding companies experience uncertainty. 


\section{The 2001 Economic Crisis of Turkey}

Ozatay (2010) explains the 2001 Economic Crisis and states that the crisis originates from Turkey's own structure and banking sector. Alpago (2002) presents the figures related to the 2001 Economic Crisis:

- Economy shrank $8.5 \%$

- GDP decreased \%25

- Business are closed (the number is 125.000)

- Bank are closed (the number is 19)

- Inflation exceed $70 \%$

- The interest rate which government pays $101 \%$ increased

- Internal debts are rised 4 times.

- At least 1.500.000 people lost their job.

The 2001 Economic Crisis follows the 2000 Economic crisis which is still affecting the economy in 2001:

Table 1 The Impacts of 2000 and 2001 Crises

$\begin{array}{lllll} & \text { Year } & \text { Year } & \text { Year } & \text { Year } \\ \text { Economic Variables } & \mathbf{1 9 9 9} & \mathbf{2 0 0 0} & \mathbf{2 0 0 1} & \mathbf{2 0 0 2} \\ \text { Unemployment (\%) } & 8.3 . & 6.9 . & 9.1 . & 11.5 . \\ \text { Underemployement rate (\%) } & 9.8 . & 7.4 . & 6.5 . & 6.1 . \\ \begin{array}{l}\text { Manufactruing Industry Employment } \\ \text { Index (1997=100) }\end{array} & & & & \\ \text {-Private Sector } & 91.7 & 90.3 & 82.5 & 84.4 \\ \text {-Public Sector } & 89.0 & 83.06 & 78.2 & 70.9 \\ & & & & \\ \text { Reel Ücret Endeksleri (1993=100) } & & & & \\ \text {-Asgari Ücret } & 123.9 & 105.8 & 91.1 & 98.4 \\ \text {-Private Sector } & 92.8 & 93.8 & 74.8 & \\ \text {-Public Sector } & 105.0 & 112.3 & 99.3 & 90.2 \\ \text {-Officer Wages } & 95.1 & 84.1 & 81.0 & 85.6\end{array}$

Source: Devlet Istatistik Enstitusu (DIE) (www.die.gov.tr)).

Table 2 1993-2006 Period Total Employement

$\begin{array}{lll}\text { Years } & \begin{array}{l}\text { Total } \\ \text { Employement } \\ 18.679\end{array} & \begin{array}{l}\text { Change } \\ \text { \%o }\end{array} \\ 1993 & 20.026 & 7.21 . \\ 1994 & 20.912 & 4.42 . \\ 1995 & 21.548 & 3.04 . \\ 1996 & 21.082 & -2.16 \\ 1997 & 22.334 & 5.94 . \\ 1998 & \end{array}$




$\begin{array}{lll}1999 & 21.507 & -3.70 \\ 2000 & 21.580 & 0.34 \\ 2001 & 21.524 & -0.26 \\ 2002 & 21.354 & -0.79 \\ 2003 & 21.147 & -0.97 \\ 2004 & 21.791 & 3.05 . \\ 2005 & 22.046 & 1.17 . \\ 2006 & 22.330 & 1.29 .\end{array}$

Source: TUIK (Turkiye Istatistik Kurumu) database

\section{Holding Companies, Related and Unrelated Diversification}

Holding companies have an important role in the economy of Turkey. Usdiken (2008) show that these companies started before legally accepted due to the fact that other countries have effects. Ustdiken (2008) describe the holding companies as a large firms possessing other firms share for longer periods of time and mention the fact that holding companies can be described with firm controlling abilities via financial instruments. Holding companies employ diversification strategies. Rumelt (1978) explains that diversification can related and unrelated.

Related diversification explains that holding companies initiates similar new busineses (Ulgen and Mirze, 2007) Core sector become the resource of growth with information, capital and human resource (Rumelt, 1982). Vertical and horizontal growths are common in this diversifaction strategy. These growths are related to core business.

Guillen (2000) assume that unrelated diversification is common in developing countries. Unrelated diversification is a strategy of picking new businesses which have not been operated by company (Schneider, 2009). New sectors can provide high profits and returns with opportunities that help to overcome company limits and managers ambitions (Ulgen and Mirze, 2007). Unrelated diversification structures consists production process, technological information and marketing abilities. Unrelated diversification become a central concept for Turkish big companies (Colpan and Hikio, 2008).

\section{Data and Methodology}

Research data is obtained from Istanbul Stock exchange. Analysis comprise 25 companies in the Borsa category of Xhold which consist of holding and investment. The research periods is 1998-2009. Annual reports of holding companies are the source of the analysis. 8 companies excluded from the sample because of the fact that their annual reports are not available for all research period.

Holding companies are coded for analysis purposes. Coding is similar to Ozkara et al. (2008) and Colpan and Hikino (2008) studies. The coding based on single system. The coding has been sent to a referee and $\% 90$ correspondence is observed. This satisfy the condition of $\% 70$ that ensure reliability (Yildirim and Simsek, 2005).

Annual reports of 1998-2009 helps to determine sectors and numbers of firms that is controlled by 17 holding companies. Two group is created according to fields of the operations which distinguish bank owning. SPSS 17.0 program is used. Mann-Whitney U test is applied. 
Therefore groups are compared with their diversifications. The main idea behind this analysis is the fact that The 2001 Economic Crisis based on a banking sector crash.

In the study, it is thought that holding companies which are owning strong banks can continue unrelated diversification against the 2001 Economic Crisis of Turkey. The analysis of the study investigate whether Turkish holding companies implements different diversification strategies after the 2001 Economic Crisis of Turkey. Bank ownership of holding companies and its effects on diversification strategies examined in the research.

The level of analysis in the research is companies which are accepted as socio-cultural systems. Populations is holding companies which have been operating in Turkey. The research is explanatory in nature and adopts a quantitative approach. The model question is "what is the relationship between the 2001 Economic Crisis of Turkey and Holding companies' diversification strategies". Dependent and independent variables of the study are presented:

Independent variable is the 2001 Economic Crisis of Turkey. Dependent variable is diversification strategies of chosen holding companies.

H1: hypothesis tests the suggestion that the crisis have an effect upon holding companies' unrelated diversification strategies.

$\mathrm{H} 2$ : hypothesis is bank owning of holding companies during the crisis have an effect upon holding companies' unrelated diversification strategies.

\section{Results}

The research explains operating fields of 17 holding companies via ISIC classification. The 4.1 classification is used in order to distinguish operating fields. Table figures show the holding companies by years.

Table 3 Holding Companies of The Research

\begin{tabular}{|c|c|c|c|c|}
\hline $\begin{array}{l}\text { Holding Company } \\
\text { Names }\end{array}$ & $\begin{array}{l}\text { Foundation } \\
\text { Year }\end{array}$ & $\begin{array}{l}\text { Holding } \\
\text { Year }\end{array}$ & Diversification & $\begin{array}{l}\text { Public } \\
\text { offering } \\
\text { year }\end{array}$ \\
\hline AKFEN HOLDING & 1976 & 1999 & Unrelated & 2010 \\
\hline ALARKO HOLDING & 1954 & 1973 & Unrelated & 1997 \\
\hline BORUSAN YAT.PAZ. & 1944 & 1972 & Unrelated & $\begin{array}{l}\text { before } \\
1998\end{array}$ \\
\hline DOGAN HOLDING & 1960 & 1997 & Related & $\begin{array}{l}\text { before } \\
1998\end{array}$ \\
\hline $\begin{array}{l}\text { DOGAN YAYIN } \\
\text { HOLDING }\end{array}$ & 1997 & & Related & $\begin{array}{l}\text { before } \\
1998\end{array}$ \\
\hline $\begin{array}{l}\text { ECZACIBASI } \\
\text { YATIRIM }\end{array}$ & 1973 & & Unrelated & $\begin{array}{l}\text { before } \\
1998\end{array}$ \\
\hline $\begin{array}{l}\text { EGELI\&CO YATIRIM } \\
\text { HOLD. }\end{array}$ & 2002 & 2010 & Related & 2010 \\
\hline $\begin{array}{l}\text { GLOBAL } \\
\text { YAT.HOLDING }\end{array}$ & 1990 & 2004 & Unrelated & $\begin{array}{l}\text { before } \\
1998\end{array}$ \\
\hline $\begin{array}{l}\text { GOZDE FINANSAL } \\
\text { HIZMET }\end{array}$ & & & Related & 2010 \\
\hline
\end{tabular}




\begin{tabular}{|c|c|c|c|c|}
\hline GSD HOLDING & 1986 & 1996 & Related & 1999 \\
\hline $\begin{array}{l}\text { ISIKLAR } \\
\text { YAT.HOLDING }\end{array}$ & 1977 & & Unrelated & 1994 \\
\hline IHLAS HOLDING & 1970 & 1993 & Unrelated & $\begin{array}{l}\text { before } \\
1998\end{array}$ \\
\hline $\begin{array}{l}\text { IHLAS YAYIN } \\
\text { HOLDING }\end{array}$ & 2003 & & Related & 2010 \\
\hline IS GIRISIM & 2000 & & Unrelated & 2004 \\
\hline ITTIFAK HOLDİNG & 1988 & 1993 & Unrelated & 2009 \\
\hline KOC HOLDING & 1926 & 1963 & Unrelated & before 1998 \\
\hline METRO HOLDING & 1977 & 2010 & Unrelated & 1988 \\
\hline NET HOLDING & 1974 & 1981 & Unrelated & 1981 \\
\hline RHEA GIRIŞIM & 1996 & & Related & 2000 \\
\hline SABANCI HOLDING & 1932 & 1967 & Unrelated & $\begin{array}{l}\text { Before } \\
1998\end{array}$ \\
\hline SISE CAM & 1934 & 1973 & Unrelated & 2000 \\
\hline $\begin{array}{l}\text { TAV } \\
\text { HAVALIMANLARI }\end{array}$ & 1997 & & Related & 2007 \\
\hline TEKFEN HOLDING & 1956 & 1975 & Unrelated & 2007 \\
\hline $\begin{array}{l}\text { TRANSTURK } \\
\text { HOLDİNG }\end{array}$ & 1940 & 1970 & Unrelated & $\begin{array}{l}\text { before } \\
1998\end{array}$ \\
\hline $\begin{array}{l}\text { YAZICILAR } \\
\text { HOLDING }\end{array}$ & 1976 & & Unrelated & 2000 \\
\hline
\end{tabular}

Table 4 Number of Operating Fields between 1998-2004

$\begin{array}{llllllll}\text { Holding Companies } & \mathbf{1 9 9 8} & \mathbf{1 9 9 9} & \mathbf{2 0 0 0} & \mathbf{2 0 0 1} & \mathbf{2 0 0 2} & \mathbf{2 0 0 3} & \mathbf{2 0 0 4} \\ \text { Alarko holding } & 3(3) & 3(3) & 3(3) & 3(3) & 3(3) & 3(3) & 4(12) \\ \text { Borusan Yatırım Pazarlama } & 1(1) & 1(1) & 1(1) & 0 & 0 & 0 & 0 \\ \text { Dogan holding } & 5(8) & 6(9) & 5(9) & 7(11) & 8(74) & 8(70) & 8(60) \\ \text { Dogan yayin holding } & 1(5) & 1(6) & 1(11) & 1(12) & 2(15) & 3(46) & 3(50) \\ \text { Eczacibsi yat.ort. } & 1(2) & 2(2) & 2(3) & 2(3) & 1(1) & 1(1) & 1(1) \\ \text { Global yatirim holding } & 2(12) & 2(13) & 2(13) & 2(13) & 2(15) & 2(12) & 2(10) \\ \text { Gsd holding } & 4(7) & 4(6) & 4(6) & 4(6) & 4(7) & 5(12) & 5(12) \\ \text { Ihlas holding } & 7(15) & 7(17) & 7(17) & 7(17) & 7(17) & 6(14) & 8(19) \\ \text { Istklar holding } & 1(2) & 1(2) & 1(2) & 1(2) & 1(2) & 1(3) & 2(5) \\ \text { Koc holding } & 4(12) & 4(11) & 5(14) & 5(16) & 5(15) & 9(61) & 9(59) \\ \text { Metro holding } & 0 & 1(1) & 1(1) & 1(1) & 1(1) & 1(1) & 1(1) \\ \text { Net holding } & 4(12) & 4(12) & 4(11) & 4(10) & 4(10) & 4(11) & 4(20) \\ \text { Rhea girisim } & 1(1) & 1(2) & 1(2) & 1(2) & 1(2) & 1(2) & 1(2) \\ \text { Sabanci holding } & 4(12) & 5(13) & 6(15) & 6(16) & 6(17) & 7(20) & 6(20) \\ \text { Sise cam } & 2(6) & 3(7) & 3(8) & 3(8) & 3(7) & 4(25) & 3(31) \\ \text { Transturk holding } & 7(10) & 7(12) & 7(12) & 7(11) & 6(10) & 6(10) & 5(7) \\ \text { Yazicilar holding } & 2(3) & 2(3) & 2(3) & 2(3) & 5(10) & 6(11) & 6(12)\end{array}$




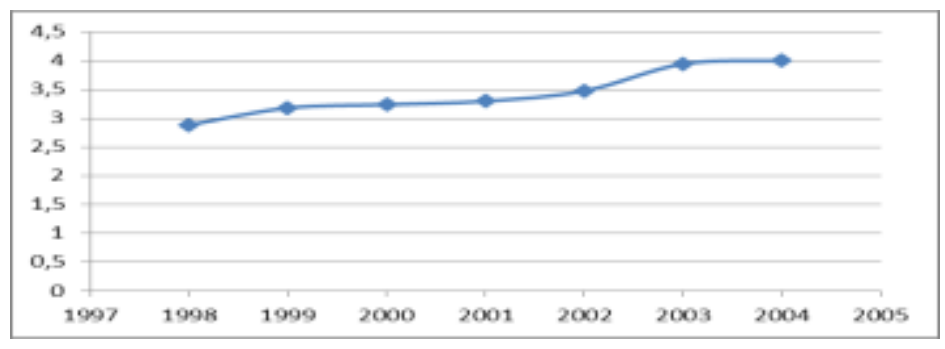

Figure 1 Holding Companies‘ 1998-2004 Years Diversification degree

Figure 1 indicates an increasing trend. This can be explained by the fact that crisis provide opportunities with unrelated diversifications. Bank ownership can support these diversifications. Tab. 5 demonstrates operating fields and yearly changes in the sample:

Table 5 Annual Changes in Operating Fields

$\begin{array}{llllllll} & \mathbf{1 9 9 8} & \mathbf{1 9 9 9} & \mathbf{2 0 0 0} & \mathbf{2 0 0 1} & \mathbf{2 0 0 2} & \mathbf{2 0 0 3} & \mathbf{2 0 0 4} \\ \text { Operating Fields } & 4 & 5 & 7 & 6 & 6 & 8 & 9 \\ \text { Information and Communication } & 1 & 1 & 1 & 1 & 1 & 2 & 2 \\ \text { Education } & 2 & 2 & 3 & 4 & 4 & 4 & 3 \\ \text { Electricity and energy } & 8 & 9 & 9 & 9 & 10 & 11 & 10 \\ \text { Finance and Insurance } & 1 & 1 & 1 & 1 & 1 & 1 & 1 \\ \text { Real Estates } & 8 & 10 & 10 & 11 & 10 & 10 & 10 \\ \text { Manufactring } & 1 & 1 & 1 & 1 & 1 & & \\ \text { Human health and Social Responsibility } & 2 & 2 & 2 & 2 & 2 & 2 & 2 \\ \text { Construction } & 4 & 4 & 4 & 4 & 4 & 5 & 7 \\ \text { Travel and Restaurants } & 2 & 2 & 2 & 2 & 3 & 3 & 3 \\ \text { Transportation } & 3 & 3 & 3 & 3 & 4 & 4 & 5 \\ \text { Profesional, scientific and technic works } & 1 & 1 & 1 & 1 & & & \\ \text { Picture, leisure and sport } & 1 & 2 & 2 & 2 & 2 & 4 & 2 \\ \text { Retails } & 8 & 9 & 8 & 8 & 9 & 10 & 10 \\ \text { Management and support services } & 2 & 2 & 2 & 2 & 3 & 3 & 4\end{array}$

It can be seen that 11 operating fields were increase in the research period. Most dramatic change is in Information and Communication area because of increasing importance of this sector. Second part of the study based on two groups. First group consists holding companies which have bank ownership before and after the crisis. Second group holding companies are the ones which do not have continuous bank ownership opportunity in research period. Mann-Whitney U test compares diversification degrees.

Table 6 presents that 2002 and 2004 years have $p<0,05$, and 2003 have $p<0,01$ level significant difference regarding research groups. This finding supports $\mathrm{H} 2$ hypothesis. 
Table 6 Mann-Whitney U test Results

$\begin{array}{llllllll} & \mathbf{A 1 9 9 8} & \mathbf{A 1 9 9 9} & \mathbf{A 2 0 0 0} & \mathbf{A 2 0 0 1} & \mathbf{A 2 0 0 2} & \mathbf{A 2 0 0 3} & \mathbf{A 2 0 0 4} \\ \text { Mann-Whitney } & 18,5 & 17,5 & 17 & 16 & 11,5 & 5,5 & 8,5 \\ \text { U } & 84,5 & 83,5 & 83 & 82 & 77,5 & 71,5 & 74,5 \\ \text { Wilcoxon W } & 8,5 & -1,636 & -1,73 & -2,181 & -2,791 & -2,478 \\ \text { Z } & -1,49 & -1,587 & 0,102 & 0,084 & 0,029 & 0,005 & 0,013 \\ \begin{array}{l}\text { Asymp. Sig. } \\ \text { (2-tailed) }\end{array} & 0,136 & 0,112 & 0,13 & & & \\ \begin{array}{l}\text { Exact Sig. } \\ \text { [2*(1-tailed }\end{array} & 0,149 & 0,122 & 0,122 & 0,098 & 0,027 & 0,003 & 0,01 \\ \text { Sig.)] } & & & & & & & \end{array}$

The table proves that bank owner holding companies diversifications are higher than others.

Table 7 Two Group Operating Field Comparisons According to Bank Owning of Holding Companies

\begin{tabular}{|c|c|c|c|c|}
\hline \multicolumn{2}{|c|}{ Banks } & $\mathbf{N}$ & $\begin{array}{l}\text { Mean } \\
\text { Rank }\end{array}$ & $\begin{array}{l}\text { Sum of } \\
\text { Ranks }\end{array}$ \\
\hline \multirow[t]{3}{*}{ A1998 } & Absence & 11 & 7,68 & 84,5 \\
\hline & Presence & 6 & 11,42 & 68,5 \\
\hline & Total & 17 & & \\
\hline \multirow[t]{3}{*}{ A1999 } & Absence & 11 & 7,59 & 83,5 \\
\hline & Presence & 6 & 11,58 & 69,5 \\
\hline & Total & 17 & & \\
\hline \multirow[t]{3}{*}{ A 2000} & Absence & 11 & 7,55 & 83 \\
\hline & Presence & 6 & 11,67 & 70 \\
\hline & Total & 17 & & \\
\hline \multirow[t]{3}{*}{ A2001 } & Absence & 11 & 7,45 & 82 \\
\hline & Presence & 6 & 11,83 & 71 \\
\hline & Total & 17 & & \\
\hline \multirow[t]{3}{*}{ A2002 } & Absence & 11 & 7,05 & 77,5 \\
\hline & Presence & 6 & 12,58 & 75,5 \\
\hline & Total & 17 & & \\
\hline \multirow[t]{3}{*}{ A2003 } & Absence & 11 & 6,5 & 71,5 \\
\hline & Presence & 6 & 13,58 & 81,5 \\
\hline & Total & 17 & & \\
\hline \multirow[t]{3}{*}{ A2004 } & Absence & 11 & 6,77 & 74,5 \\
\hline & Presence & 6 & 13,08 & 78,5 \\
\hline & Total & 17 & & \\
\hline
\end{tabular}

Table 7 presents evidence of bank owning holding companies operating fields. Number of operating fields of bank owning holding companies is larger than other holding companies in all sample periods. This tendency is increased after the 2002 economic crisis of Turkey.

\section{Conclusion}

The study aims to find out diversification strategies of Turkish holding companies in the context of the 2002 Economic crisis of Turkey. The number of holding companies that are investigated in the study is 17 . These companies are also divided into two groups in order to 
detect bank ownership impact. Since, the crisis based on banking sector crash. It is thought that the crisis can differently affect the holding companies which have constant bank ownership in analysis period.

Analysis results present that holding companies tend to increase their diversifications after the crisis. This finding can be explained with fact that crises provide investment opportunities for Turkish holding companies. Findings also suggest higher numbers of diversifications for bank owner holding companies. This magnitude rises after the 2002 economic crisis of Turkey which leads to closing of 19 banks in Turkey. It can be said that the holding companies which have an ownership of strong banks can rise their unrelated diversification easier than other holding companies.

Future studies can emphasize on different market events. European Union relationship and agreements are possible independent factors of future researches. Recent economic events like 2008 financial crises can be analysed. Macro-economic variables and policy changes can be consider in future applications.

\section{References}

Alpago, H. (2002). IMF ve Türkiye İlişkileri. İstanbul: Ötüken Yayıncılık.

Bugra, A. (1995). Türkiye'de Devlet ve İşadamları. İstanbul: İletişim Yayınları.

Chung, H.M. (2006). Managerial ties, control and deregulation: an investigation of business groups entering the deregulated banking industry in taiwan. Asia Pacific Journal Of Management, 23(4), 505-520.

Çolpan, A.M., Hikino, T. (2008). Türkiye'nin büyük şirketler kesiminde işletme gruplarının iktisadi rolü ve çeşitlendirme stratejileri. Yönetim Araştırmaları Dergisi, 8(1-2), 23-58.

Devlet İstatistik Enstitüsü. (2001). Ekonomik Panorama. Retrieved from: www. die.gov.tr/ieyd/epindeks.html.

Guillén, M.F. (2000). Business groups in emerging economies: A resourcebased view. Academy of Management Journal, 43(3), 362-380.

Karaevli, A. (2008). Türkiye'deki işletme gruplarında çeşitlenme stratejilerinin evrimi. Yönetim Araştırmaları Dergisi, 8(1-2), 85-107.

Khanna, T., \& Palepu, K. (2000). The future of business groups in emerging markets: Long-run evidence from chile. Academy of Management Journal, 43, 268-285.

Kedia, B.L., Mukherjee, D., \& Lahiri, S. (2006). Indian business groups: evolution and transformation. Asia Pacific Journal of Management, 23(4), 559.

Ozatay, F. (2010). Finansal krizler ve Türkiye. İstanbul: Doğan Kitap.

Rumelt, R.P. (1978). Diversification strategiy and profitability. Strategic Management Journal, 3, 359-369.

Schneider, R. (2009). A comparative political economy of diversified business groups, or how states organize big business. Review Of International Political Economy, 16(2), 178-201.

TUİK (2008). Istihdam Veritabanı. Retrieved from http://www.tuik.gov.tr/isgucu/IstihdamRapor.do.

Ulgen, H., \& Mirze, K. (2007). Issletmelerde Stratejik Yönetim. İstanbul: Literatür Yayıncllık.

Yildirim, A., \& Simsek, H. (2005). Sosyal Bilimlerde Nitel Araştırma Yöntemleri. Ankara: Seçkin Yayıncllık.

Usdiken, B. (2008). Türkiye'deki işletme grupları: Özel sayıya giriş. Yönetim Araştırmaları Dergisi, 8(1-2), 5-21.

Yiu, D., Bruton, G.D., \& Lu, Y. (2005). Understanding business group performance in an emerging economy: Acquiring resources and capabilities in order to prosper. Journal of Management Studies, 42(1), 183-206. 